\title{
ANALISIS PENERAPAN ASESMEN FORMATIF DALAM PEMBELAJARAN IPA DAN FISIKA : LITERATURE REVIEW
}

\author{
Dwi Putri Ramadhani ${ }^{1 *}$, Putri Nurhaliza ${ }^{2}$, Fatni Mufit ${ }^{3}$, Festiyed ${ }^{4}$ \\ 1,2,3,4Program Studi Magister Pendidikan Fisika FMIPA \\ Universitas Negeri Padang, Padang, Indonesia \\ *Corresponding Author: dwiputriramadhanif@gmail.com
}

DOI: 10.24929/lensa.v11i2.172

Received: 12 Juli 2021

Revised: 31 Oktober 2021

Accepted: 31 Oktober 2021

\begin{abstract}
ABSTRAK
Pendidikan abad 21 menuntut terciptanya siswa yang berkualitas. Penggunaan asesmen formatif pada pembelajaran merupakan cara yang dapat dilakukan dalam meningkatkan kualitas siswa.Penelitian ini bertujuan untuk melihat penerapan asesmen formatif berdasarkan hasil belajar siswa,jenjang pendidikan, materi pembelajaran, dan integrasi yang digunakan. Penelitian ini merupakan penelitian studi kepustakaan (library research) dan menggunakan pendekatan literatur review. Artikel yang digunakan terdiri dari nasional dan internasional yang berada pada rentang tahun 2015-2021. Hasil dari penelitian ini yaitu: 1)penggunaan tes formatif dapat meningkatkan berbagai hasil belajar siswa dimana yang banyak diukur yaitu pada pemahaman/penguasaan konsep, 2) Penerapan asesmen formatif lebih banyak digunakan pada jenjang SMA dibandingkan dengan jenjang SMP, 3) Penerapan asesmen formatif pada pembelajaran IPA dan fisika terdiri atas beragam materi yang menandakan asesmen formatif sering digunakan dalam pembelajaran, dan 4)terdapat berbagai macam integrasi yang digunakan dalam asesmen formatif dimana yang paling banyak digunakan adalah mengintegrasikan asesmen formatif dengan web.
\end{abstract}

Kata kunci: asesmen formatif, IPA, fisika, literatur review

\begin{abstract}
Inside the $21^{\text {st }}$ century education demands the creation of quality students. One of the methods used is to apply formative assessment in learning. The reason of this research was to determine the application of formative assessment based on student learning outcomes, education level, learning materials, and integration used. In this study using a literature study (library research) with a literature review approach. The articles used consist of national and international which arein the 2015-2021 range. The outcome of this research are: 1) the use of formative tests can improve various student learning outcomes where the most measured is the understanding/mastery of concepts, 2) the application of formative assessments is more widely used at the junior high school level compared to the high school level, 3) the application of formative assessments in science learning and physics consists of various materials which indicate formative assessment is often used in learning, and 4) there are various kinds of integration used in formative assessment where the most widely used is integrating formative assessment with the web.
\end{abstract}

Keywords: formative assessment, science, physics, literature review

\section{PENDAHULUAN}

Pendidikan abad 21 menuntut terciptanya siswa yang berkualitas. Proses pembelajaran yang dilakukan guru untuk meningkatkan intelektual, moral dan berbagai macam aneka kemampuan siswa, baik itu kecakapan berpikir, tingkat 
kreativitas, tingkat konstruksi pengetahuan, tingkat pemecahan persoalan, sampai kecakapan pemahaman materi pembelajaran secara baik, merupakan salah satu kemampuan yang perlu dikembangkan pada abad 21 (Syahputra,2018). Implementasi pembelajaran abad 21 tidak luput diikuti dengan evaluasi yang sesuai pada abad 21 . Visi penilaian abad 21 artinya penilaian tidak hanya mengukur pengetahuan berupa fakta diskrit, tetapi termasuk juga kemampuan dalam menerapkan pengetahuan secara kompleks untuk segala situasi (Winaryati,2018).

Permendikbud RI No 103 Tahun 2014 menyebutkan bahwa terdapat poin penting yang wajib ada pada rencana pelaksanaan pembelajaran (RPP) yaitu penilaian. Pada hal ini, pengajar harus mempersiapkan teknik dan mekanisme pelaksanaan penilaian serta pengukuran yang komprehensif, juga dituntut dalam berkoordinasi dengan pengajar lain, jika materi ajar bersumber dari pengajar yang tidak sama (Festiyed, 2018). Guru dapat melakukan penilaian yaitu dengan menggunakan asesmen formatif. Untuk mendapatkan hasil yang diharapkan dibutuhkan pengalaman belajar yang bervariasi. Guru diharuskan melaksanakan pembelajaran serta penilaian yang relevan dengan ciri-ciri pembelajaran abad 21 .

Fenomena yang terjadi di lapangan tidak sinkron dengan keadaan yang diinginkankan. Berdasarkan penelitian yang dilakukan oleh Kusairi (2012) asesmen formatif pada pembelajaran fisika belum terealisasi secara optimal. Kurang optimalnya penggunaan asesmen formatif diakibatkan karena 1) perencanaan dan penerapan asesmen formatif memerlukan keterampilan, pelatihan untuk melakukan asesmen formatif belum tersebar merata bagi setiap guru, 2) pengembangan instrumen, penerapan, serta analisis data tes formatif membutuhkan waktu, 3) jumlah kelas serta siswa relatif cukup banyak, 4) tidak ada instrumen baku dalam melaksanakan asesmen formatif, dan 5) tidak adanya perangkat untuk menganalisis data-data asesmen. Siswa kesulitan dalam hal menelaah fisika disebabkan karena tidak menerima/feedback dengan cepat setelah selesai mengerjakan soal (Sulistyowati,dkk.,2017). Penjelasan IPA dan fisika masih cenderung mengungkapkan konsep dan rumus terhadap siswa. Salah satu solusi dalam mengatasi permasalahan tersebut yaitu dengan menerapkan asesmen formatif pada pembelajaran IPA dan Fisika.

Pembelajaran IPA merupakan suatu kajian tentang makhluk hidup, makhluk tak hidup dan hubungan antara keduanya. Pembelajaran IPA di tingkat SMP pada kurikulum 2013 dikembangkan menjadi mata pelajaran integrative science. Pembelajaran IPA yaitu didalam satu KD telah memadukan konsep IPA berdasarkan bidang ilmu biologi, fisika, dan ilmu pengetahuan bumi serta antariksa (Festiyed, 2015).Pembelajaran IPA menekankan terhadap penyampaian konsep IPA serta penyajian penerapan konse pada permasalahan kehidupan seharihari(Hamim,dkk.,2021). Menurut Mufit,dkk (2020) fisika mengkaji alam semesta, termasuk materi dan energi pada skala kecil (mikroskopik) dan tata surya skala besar (makroskopik). Pada pembelajaran IPA dan fisika dalam mengukur hasil belajar siswa dapat menggunakan asesmen formatif.

Asesmen formatif adalah salah satu cara menyempurnakan pembelajaran.Dalam Permendikbud RI No. 104 Tahun 2014 dijelaskan bahwa asesmen formatif berfungsi dalam memperbaiki kekurangan hasil belajar siswa berupa kompetensi sikap, pengetahuan, serta keterampilan selama kegiatan pembelajaran satu semester.Pembelajaran menggunakan asesmen formatif membuat perbedaan hasil rerata pemahaman konsep yang signifikan, yang berdampak pada prestasi siswa. Penilaian formatif juga berdampak pada pembelajaran dengan praktik, diskusi,dan pembelajaran dengan sistem refleksi. Asesmen formatif diasumsikan dapat membawa dampak positif pada motivasi dan hasil belajar siswa.

Bagi pengajar dan siswa penilaian formatif mempunyai kiprah penting untuk pembelajaran. Penilaian formatif merupakan penilaian dengan tujuan memantau kemajuan belajar siswa selama kegiatan pembelajaran berlangsung pada suatu rencana pembelajaran tertentu (Ismail, 2012). Asesmen formatif mendiagnosis komponen yang masih kurang pada pembelajaran, diteruskan menggunakan feedback serta proses reflektif dan korektif dalam memberikan arah supaya terealisasikan 
ketuntasan belajar (Marsandi, dkk.,2016). Penilaian formatif memiliki tujuan memperbaiki kegiatan pembelajaran dan mendapatkan umpan balik (Sari,dkk., 2019).

Asesmen formatif banyak diterapkan dalam pembelajaran disekolah untuk meningkatkan berbagai macam hasil belajar siswa. Berdasarkan dari paparan diatas ditemukan berbagai jenis permasalahan yang berkaitan dengan hasil belajar siswa. Dalam meningkatkan hasil belajar tersebut maka pada berbagai artikel dijelaskan asesmen merupakan suatu cara yang dapat digunakan untuk meningkatkan hasil belajar. Oleh sebab itu perlu dilakukan kajian lebih dalam mengenai penerapan asesmen pada pembelajaran IPA dan fisika agar tercapai tujuan pembelajaran yang diinginkan di sekolah. Tujuan penelitian ini ialah untuk mengetahui penerapan asesmen formatif didasarkan pada hasil belajar siswa,jenjang pendidikan, materi pembelajaran, dan integrasi yang digunakan.

\section{METODE}

Pada penelitian ini memakai studi kepustakaan (library research) menggunakan pendekatan literatur review. Literatur review adalah gambaran menyeluruh dari penelitian sebelumnya tentang suatu topik tertentu (Denney \& Tewksbury, 2012). Literatur review yang dilakukan menggunakan beberapa sumber artikel yang ada diinternet. Artikel yang digunakan berada pada rentang tahun 20152021. Artikel yang dianalisis untuk literatur review berjumlah 18 artikel. Adapun rincian dari artikel yang digunakan dapat dilihat pada Tabel 1.

Tabel 1. Rincian Artikel yang Digunakan untuk Literatur Review

\begin{tabular}{clcc}
\hline No & \multicolumn{1}{c}{ Sumber Artikel } & Tahun & Kategori \\
\hline 1 & Sari,I.P, dkk & 2019 & Jurnal Nasional \\
\hline 2 & Dieni,W.E, dkk & 2017 & Prosiding Nasional \\
\hline 3 & Ulya,H, dkk & 2018 & Jurnal Internasional \\
\hline 4 & Rahmawati,S, dkk & 2019 & Jurnal Nasional \\
\hline 5 & Mufidah,J, dkk & 2020 & Jurnal Nasional \\
\hline 6 & Nuha,S.A, dkk & 2017 & Prosiding Nasional \\
\hline 7 & Nur'aini,D.A, dkk & 2020 & Jurnal Nasional \\
\hline 8 & Ningrum,A.S, dkk & 2018 & Jurnal Nasional \\
\hline 9 & Rahmawati, I,L, dkk & 2015 & Jurnal Nasional \\
\hline 10 & Lestari,D., \& Setyarsih,W & 2020 & Jurnal Nasional \\
\hline 11 & Alifiyah,C.N, dkk & 2020 & Jurnal Nasional \\
\hline 12 & Rosyad,S., dkk & 2020 & Jurnal Nasional \\
\hline 13 & Sulistyowati, dkk & 2017 & Prosiding Nasional \\
\hline 14 & Musa'adah,R., \& Kusairi,S & 2019 & Jurnal Nasional \\
\hline 15 & Lukitawanti,S.D, dkk & 2020 & Jurnal Nasional \\
\hline 16 & Parno,dkk & 2021 & Prosiding internasional \\
\hline 17 & Harizah,Z, dkk & 2020 & Prosiding internasional \\
\hline 18 & Bulunuz,N.,\& Bulunuz,M & 2017 & Jurnal internasional \\
\hline
\end{tabular}

Berdasarkan Tabel 1 diketahui secara rinci artikel yang digunakan untuk literatur review. Teknik untuk pengumpulan data pada review artikel ini yaitu pengumpulan data penelitian dengan cara tidak langsung berupa data sekunder dari penelitian yang sudah ada. Cara analisis data yang digunakan pada literatur review ini yaitu dengan cara menganalisis isi teori yang dikumpulkan. Analisis ini dilakukan dengan cara 1) mencari kesamaan dan ketidaksamaan, 2) memberikan pendapat, 3) membandingkan, dan 4) memberikan ringkasan.Langkah-langkah yang dilakukan dalam literatur review yaitu : 1) menentukan topik serta merumuskan masalah, 2) mencari bahan literatur, 3) menganalisis hasil literatur yang diperoleh, dan 4) menulis literatur review dari bahan yang telah didapatkan. 


\section{HASIL DAN PEMBAHASAN}

Artikel yang digunakan untuk literatur review adalah artikel terbit dari rentang tahun 2015-2021.Artikel yang di analisis menyajikan tentang perbandingan asesmen formatif berdasarkan kategori objek penelitian dalam bentuk berbagai hasil belajar, materi pembelajaran, jenjang pendidikan, dan integrasi yang digunakan pada asesmen formatif. Untuk lebih jelasnya data yang didapatkan dari hasil analisis artikel dapat dilihat pada Tabel 2.

Tabel 2. Analisis Data pada Artikel yang Digunakan dalam Literatur Review

\begin{tabular}{lllll}
\hline \multicolumn{1}{c}{ Penulis } & $\begin{array}{c}\text { Jenis } \\
\text { Artikel }\end{array}$ & \multicolumn{1}{c}{ Objek } & $\begin{array}{l}\text { Pelajaran } \\
\text { /Materi }\end{array}$ & Inte \\
\hline $\begin{array}{l}\text { Sari,I.P, } \\
\text { dkk }\end{array}$ & Nasional & $\begin{array}{l}\text { Pemahama } \\
\text { n konsep }\end{array}$ & $\begin{array}{l}\text { IPA/ alat } \\
\text { optik }\end{array}$ & $\begin{array}{l}\text { Pend } \\
\text { n sain }\end{array}$ \\
& & & & \\
& & & & \\
\hline Dieni,W.E, & Nasional & Pemahama & Fisika/ \\
dkk & & n konsep & $\begin{array}{l}\text { gravitasi } \\
\text { newton }\end{array}$ & \\
& & & &
\end{tabular}

\begin{tabular}{|c|c|c|c|c|}
\hline $\begin{array}{l}\text { Ulya,H, } \\
\text { dkk }\end{array}$ & Internasional & $\begin{array}{l}\text { Penguasaa } \\
\text { n konsep }\end{array}$ & $\begin{array}{l}\text { Fisika/gera } \\
\text { k harmonik } \\
\text { sederhana }\end{array}$ & $\begin{array}{l}\text { Go } \\
\text { Formatif } \\
\text { web }\end{array}$ \\
\hline
\end{tabular}

\begin{tabular}{lll}
\hline Rahmawa & Nasional & Penguasaa \\
ti,S, dkk & & n konsep
\end{tabular}

$\begin{array}{ll}\text { Fisika/ } & \text { Pendekata } \\ \text { momentum } & \mathrm{n} \text { saintifik } \\ \text { impuls } & \text { dan web }\end{array}$

Keefektivan pembelajaran

ti, S, dkk n konsep impuls dan web

menggunakan asesmen formatif pada penguasaan konsep siswa d-effect size yaitu 1,31 yang berada pada kriteria tinggi.

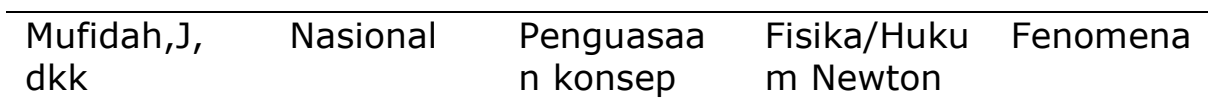

Hasil penguasaan konsep siswa saat pretes $=2.84$ meningkat saatposttes dengan skor $=10.57$. Hasil penelitian menunjukkan effect size 2.88 (kuat) dan $N$-gain 0.33 .

\begin{tabular}{llll}
\hline $\begin{array}{l}\text { Nuha,S.A, Nasional } \\
\text { dkk }\end{array}$ & $\begin{array}{l}\text { Penguasaa } \\
\text { n konsep }\end{array}$ & $\begin{array}{l}\text { Fisika/ } \\
\text { usaha dan } \\
\text { energi }\end{array}$ & Web
\end{tabular}

Nilai $t_{\text {hitung }} \geq t_{\text {tabel }}$ yaitu $3,82 \geq 1,67$. Dari nilai tersebut disimpulkan bahwa kelompok siswa dengan menggunakan formative-feedback berbasis web mempunyai penguasaan konsep fisika yang tinngi dari siswa yang menggunakan pembelajaran secara penugasan.

\begin{tabular}{|c|c|c|c|}
\hline $\begin{array}{l}\text { Nur'aini,D } \\
\text {.A, dkk }\end{array}$ & Nasional & $\begin{array}{l}\text { Penguasaa } \\
\text { n konsep }\end{array}$ & $\begin{array}{l}\text { Fisika/ } \\
\text { Hukum } \\
\text { Bernoulli }\end{array}$ \\
\hline
\end{tabular}

Dari analisis data didapatkan kategori media yang baik memberikan bukti kevalidan soal yang digunakan, efektivitas penggunaan media untuk mengetahui penguasaan konsep siswa secara cepat sehingga media disimpulkan layak.

\begin{tabular}{|c|c|c|c|c|c|}
\hline $\begin{array}{l}\text { Ningrum, } \\
\text { A.S, dkK }\end{array}$ & Nasional & $\begin{array}{l}\text { Self } \\
\text { regulation }\end{array}$ & Fisika & - & $\begin{array}{l}\text { Terdapat peningkatan pada hasil } \\
\text { belajar siswa untuk menumbuhkan }\end{array}$ \\
\hline
\end{tabular}




\begin{tabular}{llll}
\hline Penulis & $\begin{array}{c}\text { Jenis } \\
\text { Artikel }\end{array}$ & Objek & $\begin{array}{l}\text { Pelajaran } \\
\text { / Materi }\end{array}$ \\
\hline & & & \\
\hline Rahmawa & Nasional & Self & IPA/ suhu \\
ti, I,L, dkk & & regulation & $\begin{array}{l}\text { dan } \\
\text { perubahann } \\
\end{array}$ \\
& & & ya
\end{tabular}

\begin{tabular}{|c|c|c|c|c|}
\hline $\begin{array}{l}\text { Lestari,D., } \\
\& \\
\text { Setyarsih, } \\
\text { W }\end{array}$ & Nasional & $\begin{array}{l}\text { Literasi } \\
\text { sains dan } \\
\text { berpikir } \\
\text { kritis }\end{array}$ & $\begin{array}{l}\text { Fisika/pem } \\
\text { anasan } \\
\text { global }\end{array}$ & $\begin{array}{l}\text { Literasi } \\
\text { sains }\end{array}$ \\
\hline $\begin{array}{l}\text { Alifiyah,C. } \\
N \text {, dkk }\end{array}$ & Nasional & $\begin{array}{l}\text { Literasi } \\
\text { sains }\end{array}$ & $\begin{array}{l}\text { Fisika/ alat } \\
\text { optik }\end{array}$ & - \\
\hline
\end{tabular}

self-regulation siswa.

(1) $n$-gain $=0,303$; (2) $t_{\text {hitung }}=4,737$

menandakan adanya peningkatan

prestasi akademik siswa; (3)

kemampuan self regulationmemiliki peran $41 \%$ terhadap prestasi akademik siswa.

Kemampuan literasi sains serta keterampilan berpikir kritis dengn penilaian formatif pada kategori yang cukup, tinggi dan sangat tinggi.

Hasil analisis uji hipotesis $t_{\text {hitung }}>t_{\text {tabe }} l$ $=6,890>1,67$ taraf signifikans 0,05. Hal ini menandakan siswa memiliki kemampuan literasi sains yang lebih tinggi.

\begin{tabular}{lll}
\hline Rosyad,S. Nasional & Motivasi & Fisika/ \\
, dkk & belajar dan & elastisitas \\
& hasil & \\
& belajar & \\
& &
\end{tabular}

\begin{tabular}{lllll}
\hline $\begin{array}{l}\text { Sulistyow } \\
\text { ati, dkk }\end{array}$ & Nasional & $\begin{array}{l}\text { Prestasi } \\
\text { belajar }\end{array}$ & $\begin{array}{l}\text { Fisika/fluid } \\
\text { a dinamis }\end{array}$ & $\begin{array}{l}\text { Isomorphi } \\
\text { c problem }\end{array}$
\end{tabular}

Adanya dampak model pembelajaran scientific approach dengan penilaian formatif pada motivasi serta hasil belajar fisika siswa kelas XI di Madrasah Aliyah Negeri 1 Kota Malang.

Dari Hasil penelitian diketahui posttest rata-rata nilai kelompok $1=51$, $2=68$, dan $3=78$. Dari hasil tersebut dapat dikatakan bahwa feedback formatif online yang diberikan kepada siswa dalam proses pembelajaran dapat mempengaruhi prestasi belajar.

\begin{tabular}{|c|c|c|c|}
\hline $\begin{array}{l}\text { Musa'ada } \\
\text { h,R., \& } \\
\text { Kusairi,S }\end{array}$ & Nasional & $\begin{array}{l}\text { Penguasaa } \\
\text { n konsep }\end{array}$ & $\begin{array}{l}\text { Fisika/ } \\
\text { suhu dan } \\
\text { kalor }\end{array}$ \\
\hline
\end{tabular}

Pretest siswa $=34,45$ dan rata-rata posttest siswa $=66,67$, uji $N$-Gain yaitu sebesar 0,4769 kategori medium atas. Berdasarkan data tersebut diketahui bahwa pembelajaran CA menggunakan formative e-assessment dapat meningkatkan penguasaan konsep siswa.

\begin{tabular}{|c|c|c|c|c|c|}
\hline $\begin{array}{l}\text { Lukitawan } \\
\text { ti,S.D, } \\
\text { dkk }\end{array}$ & Nasional & $\begin{array}{l}\text { Kemampua } \\
\mathrm{n} \\
\text { pemecahan } \\
\text { masalah }\end{array}$ & $\begin{array}{l}\text { Fisika/ } \\
\text { elastisitas } \\
\text { dan Hukum } \\
\text { Hooke }\end{array}$ & - & $\begin{array}{l}\text { Dari penelitian didapatkan } t_{\text {hitung }}= \\
5,549>t_{\text {tabel }}=1,996 \text { dengan } \\
\mathrm{X}_{\text {eksperimen }}=72,81>\mathrm{X}_{\text {kontrol }}=65,94 \text {. } \\
\text { Dari data dapat dikatakan model } \\
\text { PjBL-STEM dengan asesmen formatif } \\
\text { berdampak pada kemampuan } \\
\text { pemecahan masalah materi pokok } \\
\text { bahasan elastisitas serta hukum } \\
\text { Hooke. }\end{array}$ \\
\hline Parno,dkk & Internasional & $\begin{array}{l}\text { Kemampua } \\
\mathrm{n} \\
\text { pemecahan } \\
\text { masalah }\end{array}$ & $\begin{array}{l}\text { Fisika/fluid } \\
\text { a statis }\end{array}$ & - & $\begin{array}{l}\text { Berdasarkan hasil penelitian } N \text {-gain } \\
0,69 \text { (kategori sedang), ukuran } d \text { - } \\
\text { effect 5,2 (kategori cukup } \\
\text { kuat),dengan } \quad \text { data tersebut } \\
\text { disimpulkan siswa mengalami }\end{array}$ \\
\hline
\end{tabular}




\begin{tabular}{|c|c|c|c|c|c|}
\hline Penulis & $\begin{array}{c}\text { Jenis } \\
\text { Artikel }\end{array}$ & Objek & $\begin{array}{l}\text { Pelajaran } \\
\text { /Materi }\end{array}$ & Integrasi & Hasil \\
\hline & & & & & $\begin{array}{l}\text { peningkatan yang signifikan pada } \\
\text { keterampilan pemecahan masalah. }\end{array}$ \\
\hline $\begin{array}{l}\text { Harizah, Z, } \\
\text { dkk }\end{array}$ & Internasional & $\begin{array}{l}\text { Keterampil } \\
\text { an berpikir } \\
\text { kritis }\end{array}$ & $\begin{array}{l}\text { Fisika/fluid } \\
\text { a statis }\end{array}$ & Web & $\begin{array}{l}\text { Berdasarkan skor } \\
\text { peningkatan kemampuan berpikir } \\
\text { kritis siswa berada pada kategori } \\
\text { sedang. Menunjukkan pembelajaran } \\
\text { dengan demonstrasi interaktif dengan } \\
\text { penilaian formatif web dapat } \\
\text { meningkatkan kemampuan berpikir } \\
\text { kritis siswa. }\end{array}$ \\
\hline $\begin{array}{l}\text { Bulunuz, N } \\
., \& \\
\text { Bulunuz,M }\end{array}$ & Internasional & $\begin{array}{l}\text { Pemahama } \\
\text { n konsep }\end{array}$ & $\begin{array}{l}\text { Fisika/kesei } \\
\text { mbangan } \\
\text { dan torsi }\end{array}$ & Instruksi & $\begin{array}{l}\text { Berdasarkan penelitian didapatkan } \\
\text { rata-rata skor pra instruksional }(M= \\
1,69, \mathrm{SD}=0,97) \text { dan skor rata-rata } \\
\text { pasca-pengajaran }(\mathrm{M}=2,69, \mathrm{SD}= \\
0,73)(\mathrm{t}(25)=5, \mathrm{p}<0,05) \text {. Hasil ini } \\
\text { menatakan penilaian formatif } \\
\text { mempengaruhi pemahaman konsep } \\
\text { siswa. }\end{array}$ \\
\hline
\end{tabular}

Berdasarkan Tabel 2 dapat diketahui deskripsi dari artikel yang digunakan untuk literatur review tentang penerapan asesmen formatif dalam pembelajaran IPA dan Fisika. Artikel yang digunakan berjumlah 18 artikel. Dari artikel yang ada dapat diperoleh beberapa penjelasan tentang penerapan asesmen formatif.

\section{Penerapan Asesmen Formatif Berdasarkan Hasil Belajar Siswa}

Berdasarkan artikel yang telah dianalisis didapatkan hasil bahwa asesmen formatif dapat melengkapi pembelajaran dengan meningkatkan hasil belajar siswa. Asesmen formatif adalah salah satu cara untuk menyempurnakan proses pembelajaran (Marsandi, 2016). Salah satu aspek yang menunjang peningkatan hasil belajar siswa yaitu menganalisis terlebih dahulu kompetensi awal siswa dan segala aspek yang digunakan disekolah dalam menunjang kegiatan pembelajaran sebelum melaksananakan penilaian. Sehingga dapat dilihat kompetensi siswa yang mengalami peningkatan melalui instrumen penilaian yang disusun dan dilaksanakan. Beberapa hasil pembelajaran yang dapat dilihat dengan menggunakan asesmen formatif yaitu :

\section{Pemahaman/Penguasaan Konsep}

Berdasarkan dari artikel yang telah dianalisis salah satu hasil belajar yang dapat ditingkatkan dengan menerapkan asesmen formatif dalam pembelajaran yaitu pemahaman/penguasaan konsep siswa. Dari artikel yang dianalisis pemahaman/penguasaan konsep merupakan objek yang paling banyak diteliti dengan menggunakan asesmen formatif. Dari 18 artikel untuk pemahaman/penguasaan konsep terdiri dari 9 artikel. Dapat dikatakan bahwa asesmen formatif bisa digunakan untuk melihat pemahaman/penguasaan konsep siswa. Dari artikel yang digunakan diketahui bahwa peneliti mengungkapkan pemahaman/penguasaan konsep siswa meningkat dengan asesmen formatif melalui hasil nilai rata-rata pretest-postest,effect size, $N$-gain, serta $t_{\text {hitung. }}$. Asesmen formatif yang dipakai guru pada proses pembelajaran dapat meningkatkan pemahaman/ penguasaan konsep yang dimiliki oleh siswa. Hal ini dibuktikan oleh Dieni,dkk (2017) dalam penelitiannya bahwa siswa yang mendapat umpan balik formatif memiliki pemahaman konsep yang lebih tinggi. Pembelajaran yang disertai e-asesmen formatif dapat meningkatkan penguasaan konsep siswa (Musa'adah \& Kusairi,2019).

\section{Self Regulation}

Berdasarkan artikel yang didapatkan terdapat dua artikel yang membahas tentang pengaruh asesmen formatif terhadap self regulation siswa. Jumlah artikel ini menandakan belum banyaknya peneliti melihat pengaruh asesmen formatif terhadap self regulation. Penerapan asesmen formatif dalam pembelajaran dapat memberikan dampak positif bagi siswa. Asesmen formatif dapat meningkatkan keterampilan self 
regulation pada siswa baik siswa jenjang SMP maupun SMA. Hal ini dibuktikan dengan penelitian yang dilakukan oleh Rahmawati,dkk (2015) menjelaskan bahwa penerapan asesmen formatif meningkatkan kemampuan self regulation siswa SMP yang ditandai dengan nilai $n$-gain $=0,303$. Adapun penelitian yang dilakukan oleh Ningrum,dkk (2018) menunjukkan bahwa terdapat peningkatan hasil belajar dalam menumbuhkan self-regulation siswa pada jenjang SMA. Yang ditunjukkan oleh hasil posttest lebih besar dari hasil pretest.

\section{Literasi Sains dan Berfikir Kritis}

Pembelajaran dengan menerapkan asesmen formatif dapat meningkatkan kemampuan siswa yang dituntut pada abad 21 yaitu literasi sains serta berpikir kritis. Penelitian yang telah dilakukan oleh Lestari \& Setyarsih (2020) mengatakan bahwa Keterampilan berpikir kritis serta literasi sains dengan menggunakan penilaian formatif berada pada kategori cukup, tinggi dan sangat tinggi. Penelitian oleh Alifiyah,dkk (2020) menyebutkan bahwa siswa yang belajar dengan asesmen formatif dapat meningkatkan literasi sains yang lebih tinggi.

\section{Motivasi Belajar dan Hasil Belajar}

Artikel yang membahas mengenai motivasi belajar maupun hasil belajar hanya terdiri dari satu artikel. Hal ini menandakan bahwa masih sedikitnya penelitian tentang penerapan asesmen formatif pada motivasi maupun hasil belajar siswa. Tetapi pembelajaran yang dilakukan dengan bantuan asesmen formatif dapat meningkatkan hasil belajar siswa selama pembelajaran. Berkaitan terhadap penelitian yang dilakukan Rosyad,dkk (2020) menyebutkan bahwa adanya dampak positif model scientific approach disertai penilaian formatif dalam meningkatkan motivasi belajar maupun hasil belajar fisika pada siswa.

\section{Prestasi Belajar}

Dari 18 artikel yang digunakan pada literatur review ini terdapat satu artikel yang membahas tentang prestasi belajar siswa. Angka ini menunjukkan masih jarangnya penelitian tentang penerapan asesmen formatif pada prestasi belajar siswa. Akan tetapi berdasarkan penelitian yang dilakukan oleh Sulistyowati, dkk (2017) menjelaskan bahwa feedback formatif yang diberikan berdampak positif pada prestasi belajar siswa.Maka bisa dikatakan asesmen formatif bisa diterapkan dalam pembelajaran untuk menigkatkan prestasi belajar siswa.

\section{KemampuanPemecahan Masalah}

Dari 18 artikel yang dianalisis terdapat dua artikel yang meneliti tentang penerapan asesmen formatif terhadap kemampuan siswa pada pemecahan masalah. Penggunaan asesmen formatif pada pembelajaran mampu memberikan efek positif pada keterampilan pemecahan masalah siswa. Hal ini dibuktikan melalui penelitian yang dilakukan oleh Lukitawanti,dkk (2020) menyatakan bahwa model PjBL-STEM disertai asesmen formatif mampu meningkatkan keterampilan pemecahan masalah. Hal ini didukung dengan penelitian oleh Parno,dkk (2021) mengatakan siswa mengalami peningkatan pada keterampilan pemecahan masalah saat menerapkan formatif asesmen dalam pembelajaran.

\section{Penerapan Asesmen Formatif Berdasarkan Jenjang Pendidikan}

Asesmen formatif dapat diterapkan pada berbagai jenjang pendidikan seperti SMP dan SMA. Pertama pada jenjang pendidikan SMP. Penelitian yang dilakukan oleh Sari,dkk (2019) dan Rahmawati,dkk (2015) menyatakan bahwa asesmen formatif memberikan dampak positif bagi siswa untuk jenjang pendidikan SMP khususnya pada pembelajaran IPA di sekolah. Dampak positif yang diberikan yaitu terhadap pemahaman konsep dan self regulation. Kedua, berdasarkan jenjang pendidikan SMA. Beberapa penelitian yang dilakukan oleh Dieni,dkk (2017); Ulya,dkk (2018) ;Rahmawati,S, dkk (2019);Mufidah,dkk (2020); Nuha,dkk (2017); Nur'aini,dkk (2020), Ningrum,dkk(2018); Lestari\& Setyarsih (2020); Alifiyah,dkk (2020), Rosyad,dkk (2020);Sulistyowati, dkk (2017); Musa'adah\& Kusairi (2019); Lukitawanti,dkk (2020);Parno,dkk (2021); Harizah,Z (2020); Bulunuz,N \& Bulunuz,M (2017) menyebutkan bahwa asesmen formatif memberikan dampak positif bagi siswa untuk jenjang pendidikan SMA khususnya pada pembelajaran fisika di sekolah. Dampak positif yang diberikan yaitu terhadap pemahaman dan penguasaan 
konsep, self regulation, literasi sains dan berpikir kritis, motivasi belajar serta hasil belajar, prestasi belajar dan juga terhadap kemampuan pemecahan masalah. Untuk jumlah artikel pada jenjang SMP jauh lebih sedikit dibandingkan dengan jenjang SMA. Berdasarkan hal ini diketahui bahwa penerapan asesmen formatif pada jenjang SMA lebih banyak digunakan dibandingkan dengan jenjang SMP.

\section{Penerapan Asesmen Formatif Berdasarkan Materi Pembelajaran}

Berdasarkan dari artikel yang dianalisis diketahui bahwa asesmen formatif sering digunakan dalam pembelajaran fisika. Hal ini dapat dilihat bahwa banyak materi yang diuji cobakan dalam berbagaipembelajaran fisika. Dari artikel penerapan asesmen formatif terdiri dari beragam materi yaitu gravitasi Newton, gerak harmonik sederhana, momentum impuls, hukum Newton, usaha dan energi, hukum Bernoulli, pemanasan global, alat optik, elastisitas, fluida dinamis, fluida statis, suhu dan kalor, keseimbangan dan torsi. Berdasarkan hal ini maka dapat diketahui asesmen formatif cocok digunakan untuk meninjau hasil belajar fisika siswa. Penilaian yang dilakukan dengan asesmen formatif dapat meningkatkan berbagai hasil belajar siswa jika diimplementasikan dalam pembelajaran fisika disekolah.

Peningkatan dapat dilihat pada aspek pemahaman konsep siswa seperti penelitian yang dilakukan oleh Dieni,dkk (2017);Ulya,dkk (2018);Rahmawati,dkk (2019);Mufidah dkk(2020);Nuha,dkk(2017);Nur'aini,dkk(2020);Musa'adah \& Kusairi(2019);Bulunuz,N \& Bulunuz,M (2017). Untuk aspek self regulation penerapan asesmen formatif ini dapat meningkatkan hasil belajar siswa dalam menumbuhkan self-regulation siswa, hal ini terdapat dalam penelitian (Ningrum,dkk.,2018).Penggunaan asesmen formatif dapat meningkatkan literasi sains serta kemampuan berpikir kritis (Lestari \& Setyarsih,2020 ;Alifiyah,2020; Harizah,Z,2020). Selain itu penerapan asesmen formatif dapat meningkatkan motivasi belajar, hasil belajar, dan kemampuan pemecahan masalah siswa.Berdasarkan hasil yang telah dipaparkan maka dapat kita simpulkan bahwa penerapan asesmen formatif dalam pembelajaran fisika diterapkan dalam berbagai materi untuk mengukur berbagai hasil belajar fisika siswa.

Dari artikel yang dikumpulkan penerapan asesmen formatif juga diterapkan dalam pembelajaran IPA. Untuk jumlah artikel pada pembelajaran IPA jauh lebih sedikit dibandingkan dengan fisika. Asesmen formatif untuk pelajaran IPA didapatkan dua artikel dimana terdiri dari materi alat optik dan suhu dan perubahannya. Penerapan asesmen dalam IPA dapat meningkatkan penguasaan konsep siswa sesuai dengan penelitian dari Sari,dkk (2019) dimana mengintegrasikan penilaian formatif formal serta informal pada pembelajaran IPA dengan pendekatan saintifik memberikan dampak yang signifikan terhadap peningkatan pemahaman konsep siswa. Selain itu, asesmen formatif juga dapat menigkatkan kemampuan self regulation. Hal ini sesuai dengan penelitian Rahmawati,dkk (2015) kemampuan self regulation siswa meningkat dengan diterapkannya asesmen formatif dalam pembelajaran.

\section{Penerapan Asesmen Formatif Berdasarkan Integrasi yang Digunakan}

Berdasarkan artikel yang dikumpulkan tentang asesmen formatif dapat kita tinjau berdasarkan integrasi yang digunakan dalam asesmen. Dari artikel yang ada diketahui bahwa terdapat berbagai macam integrasi yang digunakan dalam asesmen formatif seperti pendekatan saintifik, web, go formatif web, pendekatan saintifik dan web, fenomena, komputer, literasi sains,isomorphic problem, dan instruksi. Berdasarkan hal ini maka diketahui bahwa penerapan asesmen formatif dalam pembelajaran fisika dan IPA beragam. Untuk integrasi yang terbanyak digunakan adalah asesmen formatif diintegrasikan dengan web. Dalam kondisi saat ini pengintegrasian web cocok digunakan karena pembelajaran dilakukan secara daring atau jarak jauh. Penerapan asesmen formatif yang terdiri dari berbagai macam integrasi ini terbukti dapat meningkatkan berbagai hasil belajar dalam pembelajaran fisika dan IPA dapat dilihat dalam Tabel 2. 


\section{KESIMPULAN}

Berdasarkan hasil literatur review dari 18 artikel dapat diambil beberapa kesimpulan. Pertama penggunaan tes formatif dapat meningkatkan berbagai hasil belajar yaitu penguasaan konsep, self regulation, literasi sains dan berpikir kritis, motivasi belajar, prestasi belajar, dan keterampilan pemecahan masalah siswa. Pada umumnya asesmen formatif ini digunakan dalam melihat pemahaman/penguasaan konsep siswa. Kedua penerapan asesmen formatif lebih banyak digunakan pada jenjang SMA dibandingkan dengan jenjang SMP. Ketiga penerapan asesmen formatif ditinjau dari materi pembelajaran fisika terdiri atas beragam materi seperti gravitasi Newton, gerak harmonik sederhana, momentum impuls, hukum Newton, usaha dan energi, hukum Bernoulli, pemanasan global, alat optik, elastisitas, fluida dinamis, fluida statis suhu dan kalor, keseimbangan dan torsi. Asesmen formatif berdasarkan materi IPA yaitu materi alat optik dan suhu dan perubahannya. Keempat terdapat berbagai macam integrasi yang digunakan dalam asesmen formatif seperti pendekatan saintifik, web, go formatif web, pendekatan saintifik dan web, fenomena, komputer, literasi sains,isomorphic problem dan instruksi. Integrasi yang paling banyak digunakan dengan asesmen formatif adalah dengan web.

\section{SARAN}

Bagi peneliti selanjutnya perlu untuk melakukan analisis yang lebih lanjut untuk berbagai aspek yang berpengaruh dengan penggunaan asesmen formatif dalam pembelajaran IPA dan fisika. Penggunaan sumber artikel untuk review artikel agar dapat lebih banyak lagi dengan tema yang sejenis yang berasal dari artikel nasional terkareditasi maupun internasional supaya menghasilkan penelitian yang lebih baik.

\section{DAFTAR PUSTAKA}

Alifiyah,C.N., Parno., \& Kusairi, S. (2020). Efektivitas Penggunaan UKBM Terhadap Literasi Sains Materi Alat Optik Dalam Model PjB-STEM Dengan Asesmen Formatif Pada Siswa Kelas XI MIA SMA Negeri 9 Malang. BRILIANT : Jurnal Riset dan Konseptual, 5(4), 679-686.

Bulunuz,N., \& Bulunuz,M. (2017). Effect of Formative Assessment-Based Instruction on High School Students' Conseptual Understanding of Balance and Torque. Journal of Inquiry Based Activities (JIBA), 7(1), 21-33.

Denney,A.S., \& Tewksbury,R. (2012). How to Write a Literature Review. Journal of Criminal Justice Education, 24(2), 218-234.

Dieni,W.E., Sujito., Sugiyanto., \& Kusairi,S. (2017). Pengaruh Formative Feedback Berbasis Web Terhadap Pemahaman Konsep Siswa Kelas X SMAN 1 Lawang tentang Gravitasi Newton. Seminar Nasional Fisika dan Pembelajarannya, 44-50.

Festiyed, F. (2018). Studi pendahuluan pengimplementasian Kurikulum 2013 dalam mengintegrasikan pendekatan saintifik melalui model inkuiri dan authentic assessment dalam pembelajaran IPA di Kota Padang.SEMIRATA, Universitas Tanjung Pura Pontianak 6-9 Mai 2015.

Festiyed. (2015). Studi Pendahuluan Pengimplementasian Kurikulum2013 dalam Mengintegrasikan Pendekatan Saintifik Melalui Model Inkuiri dan Authentic Assessment dalam Pembelajaran IPA di Kota Padang. SEMIRATA Universitas Tanjung Pura Pontianak, 2015 Mai,1-12.

Hamim,L.,Fajarianingtyas,D.A., \&Hidayat,J.N. (2021).Pengembangan Petunjuk Praktikum Berbasis Masalah Memuat Literasi Sains Siswa SMP Kelas VIII. Lensa (Lentera Sains) : Jurnal Pendidikan IPA, 11(1), 31-37. 
Harizah,Z., Kusairi,S., \& Latifah,E. (2020). Student's Critical Thinking Skills in Interactive Demonstration Learning with Web Based Formative Assessment. Journal of Physics: Conference Series, 1567 : 042038, 1-6.

Ismail,M.I. (2012). Pengaruh Bentuk Penilaian Formatif Terhadap Hasil Belajar IPA Setelah Mengontrol Pengetahuan Awal Siswa. Lentera Pendidikan, 15(2), 175191.

Kusairi,S. (2012). Analisis Asesmen Formatif Fisika SMA Berbantuan Komputer. Jurnal Penelitian dan Evaluasi Pendidikan, Vol 16, 68-87.

Lestari,D., \& Setyarsih,W. (2020). Kelayakan Instrumen Penilaian Formatif Berbasis Literasi Sains Peserta Didik pada Materi Pemanasan Global. IPF : Inovasi Pendidikan Fisika, 9(3), 561-570.

Lukitawanti,S.D., Parno., \& Kusairi,S. (2020). Pengaruh PjBL-STEM Disertai Asesmen Formatif terhadap Kemampuan Pemecahan Masalah pada Materi Elastisitas dan Hukum Hooke. JRPF (Jurnal Riset Pendidikan Fisika), 5(2), 83-91.

Marsandi., Kusairi,S., \& Suwono. (2016). Pengembangan Asesmen Formatif pada Materi Indra Penglihatan dan Alat Optik. Prosiding Seminar Nasional II Tahun 2016, 410-422.

Mufidah,J., Parno., \& Diantoro,M. (2020). Penguasaan Konsep Siswa dalam Argumen Driven Inquiry Berbasis Fenomena Disertai Penilaian Formatif. BRILIANT : Jurnal Riset dan Konseptual, 5(4),749-761.

Mufit,F., Asrizal., \& Puspitasari,R. (2020).Meta-Analysis of the Effect of Cognitive Conflict on Physics Learning. JPPPF (Jurnal Penelitian dan Pengembangan Pendidikan Fisika), 6(2), 267-277.

Musa'adah,R., \& Kusairi,S. (2019). Analisis Penguasaan Konsep Siswa Materi Suhu Kalor pada Pembelajaran Cognitive Apprenticeship (CA) disertai Formative EAssessment. JRPF (Jurnal Riset Pendidikan Fisika), 4(2), 85-90.

Ningrum,A.S., Ertikanto,C., \& Rosidin,U. (2018). Development of Formative Assessment Models by Guided-Inquiry Based to Foster Self Regulation of Student High School. Jurnal Pendidikan Fisika Universitas Muhammadiyah Metro, 6(1), 100-116.

Nuha,S.A., Kusairi,S., \& Sujito. (2017). Pengaruh Implementasi Formative Feedback Berbasis Web dengan Menggunakan Butir Isomorik Terhadap Penguasaan Konsep Fisika Siswa SMA Pokok Bahasan : Usaha dan Energi. Seminar Nasional dan Pembelajarannya, 128-137.

Nur'aini, D.A., Lestari,P.D., \& Kurniawan,B.R. (2020). Pengembangan Asesmen Formatif Berbasis Komputer untuk Mengetahui Penguasaan Konsep Siswa pada Materi Hukum Bernoulli. Jurnal Riset Pendidikan Fisika, 5(2), 106-112.

Parno., Estianinur., \& Latifah,E. (2021). The Increase of Problem Solving Skills of Students through STEM Integrated Esperiental Learning with Formative Assessment.AIP Conference Proceedings, 2331 : 030021,1-8.

Permendikbud RI No 103 Tahun 2014 Tentang Pembelajaran pada Pendidikan Dasar dan Pendidikan Menengah.

Permendikbud RI No. 104 Tahun 2014 Tentang Asesmen Hasil Belajar. 
Rahmawati,I.L., Hartono., Nugroho,S.E. (2015). Pengembangan Asesmen Formatif untuk Meningkatkan Kemampuan Self Regulation Siswa pada Tema Suhu dan Perubahannya. Unnes Science Education Journal, 4(2), 842-850.

Rahmawati,S., Kusairi,S., \& Sutopo. (2019). Analisis Penguasaan Konsep Siswa yang Belajar Materi Momentum dan Impuls Berbasis Scientific Approach Disertai Formative Assessment Berbantuan Web. 2019. Jurnal Pembelajaran Sains, 3(1), 1-6.

Rosyad,S., Diantoro,M., \& Kusairi,S. (2020). Pengaruh Scientific Approach Berbantuan Penilaian Formatif terhadap Motivasi Belajar dan Hasil Belajar Fisika Siswa Kelas XI pada Materi Elastisitas. Jurnal Pendidikan : Teori, Penelitian, dan Pengembangan, 5(10), 1480-1484.

Sari,I.P., Mustikasari,V.R., \& Pratiwi,N. (2019). Pengintegrasian Penilaian Formatif dalam Pembelajaran IPA Berbasis Saintifik Terhadap Pemahaman Konsep Peserta Didik.Jurnal Pendidikan IPA Veteran, 3(1), 52-62.

Sulistyowati., Sujito., \& Kusairi,S. (2017). Pengaruh Pemberian Feedback Formatif Online Materi Fluida Dinamis Berbasis Isomorphic Problems Terhadap Prestasi Belajar Siswa. Seminar Nasional Fisika dan Pembelajarannya, 51-58.

Syahputra, E.(2018). Pembelajaran abad 21 dan penerapannya di Indonesia. In Prosiding Seminar Nasional SINASTEKMAPAN ,1(1), 1277-1283.

Ulya,H., Maulida,L., Aini,N., \& Ainur,D. (2018). Westlive : Web-Based Assessment for Learning Using Go ormative Application for Improving Student's Physics Concept Mastery. International Innovation, Design and Articulation i-IdeA, Vol 1, 174179.

Winaryati, E. (2018). Penilaian kompetensi siswa abad 21. In Prosiding Seminar Nasional \& Internasional, 6-19. 